\title{
What Constitutes Poverty in Myanmar? The Social Work Appraisal
}

\author{
Henry Ngun Ceu Thang', Nguyen Thi Tung Uyen², Ndungi wa Mungai ${ }^{3, *}$ \\ ${ }^{1}$ School of Social Sciences, Universiti Sains Malaysia, and Managing Director of Myanmar Education for Development and Social Work \\ ${ }^{2}$ Social Work Department, School of Social Sciences, Universiti Sains Malaysia, Malaysia \\ ${ }^{3}$ Charles Sturt University, Australia \\ *Corresponding Author: nmungai@csu.edu.au
}

\begin{abstract}
This paper briefly describes the general poverty situation in Myanmar, factors that partly constitute poverty in Myanmar, and social work and poverty in Myanmar. Myanmar with a population of over 60 million and at $676,578 \mathrm{~km} 2$ (Burma) is the largest country of mainland Southeast Asian Region, and second largest overall in size after Indonesia. It is a country that is rich in natural resources including precious stones, oil, and natural gas, however, Myanmar is still one of the poorest countries and majority of its citizens are still living in poverty and do not enjoy the benefit of their rich natural resources even under the newly introduced political reforms. There are differences in urban and rural poverty. The urban people have more money than the rural people but rural people on subsistence agriculture have more food but no hard cash. It is argued in this paper that poverty in Myanmar is mainly caused by the mismanagement of resources and inefficiency of governance, corruption and dishonesty in resource allocations, insecurities of social and economic conditions to the people. The 2008 Myanmar Constitution describes the protection and rights of the citizens for property ownership, education and health. The newly adopted pro-market reforms have led to cases of land seizures from farmers for mining and industrial development, decline in wages in real terms for factory workers with resultant social problems in many areas in the country. The challenge for the future leaders and policy makers is whether it is the constitution that needs to be changed or improved or improve the enforcement of the current one to improve the poverty situation for the people of Myanmar.
\end{abstract}

Keywords Myanmar, Poverty, Social Work, Development

\section{Introduction}

Poverty is still one of the main social and economic issues to many Myanmar citizens. The mismanagement of the natural resources in the past might have been the principle reason for the current conditions. The challenge which the policy makers and planners need to address is why Myanmar is still one of the poorest countries in South East Asia and why the country is still facing serious poverty issues despite being widely acknowledged as resource rich country. The investment in natural gas, power generation, timber and mining may make money for the country but the issue is how they benefit the ordinary people.

New political reforms were introduced, International Non Government Organizations and Local Non Government Organizations, many religious and civil society organizations are also operating in the country to address the poverty. However, these organizations in Myanmar need to be more proactive in promoting the rights of the people and addressing poverty, as Mai Run Pen pointed out;

To be able to lobby on making new legal provisions to protect the people's rights. They need to engage in social development activities or services to promote the rights of various groups such as children, women, and all less privileged sector of the society. They have to try to promote rights such as the right to education, and the right to health, etc (Pen, 1995, p.15).

While some aspects of human rights have been promoted in the country under the new government such as the release of political prisoners and ceasefires with many of the armed minority groups, there is a lot more to be done. The question broad areas that urgently need to be addressed includes religious and political, social justice, and the rights and the freedom for the people to make their own choice for their future. The challenge facing the country in the light of recent political changes is whether this will translate into tangible changes in a positive way in terms of income, wellbeing and human rights.

Myanmar and its citizens are usually identified with poverty and it is noted that 'Myanmar is a very poor country. The economy of the country is partially dependent on its agriculture and also on its export trade' (Myanmar in World Map).Poverty is recognized by the United Nations as a social and an economic issue to be addressed through Millennium 
Development Goals (MDGs). As social work deals with individual and communities and is also concerned with policies from local to the national and international level, one cannot ignore the role of governance in uplifting the socio-economic conditions of the people. It is therefore crucial for social workers to establish the basic factors that constitute and contribute to poverty in Myanmar.

\section{Defining Poverty and Poor}

Poverty is experienced ad defined by different people differently depending on their personal, socio-cultural and economic situation. Marshall (1998) defines poverty in terms of lack of resources, mainly material but could also be cultural. Marshall also distinguishes absolute from relative poverty with the former being predominant in developing countries and the later is the feature of developed countries where individuals or groups may lack resources to enable them to enjoy the same standard of living as others who are better off in the same society.

Poverty needs to be understood in context, Jung (1990) argues that the poor might be classified as socially poor meaning that their social status are deprived, economically poor where economic opportunities are denied and politically poor in situations where freedom of choice for their own betterment is suppressed. To define this in the Korean context, the poor are referred to as 'Minjung.' Jung describes the different manifestations of poverty in Korea:

The Minjung are the poor, but by poor we mean not only those who are poor in money but also in power, in social status, and by the standards of the present order, in educational attainment. They are those who are politically oppressed, economically exploited, socially marginalised and culturally deprived (Jung, 1990, p.21).

In the Korean context then being a 'Minjung' or poor is more than having a low income. The ideas informing 'Minjung' reflect the Korean struggles against imperial powers such as Japan and China and internal repressions under dictators such as Park Chung-hee in power in 1963-1979. 'Minjung', however, is more than a term for the poor as it also includes art, theology, and an activist movement that struggles for human rights, social justice and democratization as well as autonomy and reunification in their foreign affairs position (Kuster, 1994).

\section{Poverty in Myanmar}

According to the Poverty Profile Report for 2009-2010 conducted by United Nations Development Program (2011), in Myanmar there were five members in one household on average in Myanmar, and poverty afflicts around $25 \%$ of the population which has significantly fallen by $6 \%$ since 2005 . They pointed out that the rural poverty accounts for almost $85 \%$ of the total poverty. According to this report, $54 \%$ of poor households were working in agriculture, hunting and forestry, compared to $6 \%$ working in manufacturing sector. For labor force, they found that $67 \%$ of the population was from poor population which they conclude that poverty is not a consequence of non-participation in economic activities but rather it is due to low returns for those who participate in economic activities. According to the report, 53\% of the households had quality roofing access, $70 \%$ had access to drinking water, and $48 \%$ to electricity in 2010 . In terms of health, access to health care stood at $81 \%$, literacy rate stood at $90 \%$ in 2010 .

Saha (2011) pointed out that $32 \%$ of Myanmar population lived below poverty line (ADB and Myanmar Fact Sheet 2010; Saha 2011), and also noted that the Myanmar government expenditure on health and education were $0.5 \%$ and $1.3 \%$ of GDP respectively. Using the findings by Saha, one can conclude that the expenditures for the very basic needs for the general people in health and education sectors are quite low. Situation Analysis of Children in Myanmar points out that the low investment in health and education, especially in rural areas, accounts for poverty and deprivation as well as the poor quality of services:

Spending in the social sector is very low and health and education combined for 1.5 per cent share of GDP between 2000 and 2007 (far short of other ASEAN countries average), with the bulk of spending on education ( 78 per cent). The low public resource allocation for the social sector impacts on service delivery, leading to, for example services not being available (particularly in remote areas) or not being of adequate standard; insufficient personnel, especially trained service providers; low salary levels and low investment in capacity development. There are additional issues in relation to planning and coordination, organization and management, and monitoring and accountability (Situation Analysis of Children in Myanmar, 2012).

According to civil liberties leader Aung San Suu Kyi, current government's poverty alleviation strategies are critical as she believes that $70 \%$ of Myanmar population remains unemployed and hopeless for their future despite the attempts by the current government. She identified six sectors that have to be prioritized to meet the pressing needs of the ordinary citizens: (1) jobs (2) water (3) roads (4) electricity (5) education and (6) health (Myanmar Newsweek, 2013). She believes if those needs are fulfilled, there will be better living conditions for the people. At the same time, around $70 \%$ of population live in the rural areas where they are working in agriculture related economic activities, and she noted that there were allegations of land seizures. She argued that if people from the north, the south, the east and the west in Myanmar were asked about what they needed most, their answer would be the same. They need jobs. World Bank identifies improvement in the infrastructure as the key to poverty alleviation as people cannot access services and services cannot reach people especially during the monsoon season when roads are impassible:

Myanmar is one of the poorest countries in East Asia, with 
an estimated GDP per capita of between $\$ 800-\$ 1,000$ and a poverty headcount of 26 percent. The country's GDP is estimated at US\$50 billion. Most social indicators are very low. For example, 32 percent of children under five suffer from malnutrition. The poor state of and limited access to infrastructure are major impediments to providing basic health and education services, and for economic development. Almost half the roads are not passable during the monsoon season. Telecommunications and internet access is also very limited (World Bank, 2013).

Discussing poverty as a social and economic reality in Myanmar should not be regarded as being pessimistic and ignoring the efforts of those who have been involved in social work and other development areas throughout the decades with many evident achievements. However, the reality is, despite attempts from government, non-government organizations, and even individuals, poverty still remains the real issue and the majority of the people are still living in poverty. One has to ask why ignorance, sickness, illiteracy, and economic exploitation such as underpaid or low pay to workers still rampant and visible everywhere in the society today. There many people who are still hungry, without adequate clean water, and security. The rights for farmers to own land to till, and just wages to workers in the industries are challenges as farmers cry for their land ownerships and workers call for the right wages in an ongoing struggle for justice.

\section{Governance and Poverty}

The causes and solutions to poverty in Myanmar are complex. Anecdotal evidence suggests that it might have caused by mismanagement over natural resources or inefficient governance in the past decades. It is stated that Myanmar is a county that is a resource-rich but, suffers from pervasive government controls, inefficient economic policies, and rural poverty (Economy of Burma). For many people in Myanmar, the blame lies squarely on the past governments. Myanmar, during the British were in the country, was the wealthiest country in Southeast Asia and the largest exporter of rice in the world (Economy of Burma).

\section{Corruption}

Corruption is the one word that characterizes the governance of many developing countries. In Myanmar, it has been endemic due to lack of transparency and accountability under the previous governments. It is a big problem for national governments in developing countries which hinders development projects implementations for rural as well as urban areas. If corruption is rampant in society, genuine development can be delayed or distorted as funds ending up in private hands of well-connected members in the ruling elite. Corruption has been one of the issues raised by many people in concluding one of major issues that caused poverty in Myanmar. It is the reality that no country, even first world countries, is completely untainted by corruption. According to Transparency International on their Corruption Perceptions Index 2012, corruption as an international problem that harms communities and derails development programs, particularly those badly needed by the poor:

Looking at the Corruption Perceptions Index 2012, it's clear that corruption is a major threat facing humanity. Corruption destroys lives and communities, and undermines countries and institutions. It generates popular anger that threatens to further destabilise societies and exacerbate violent conflicts.

The Corruption Perceptions Index scores countries on a scale from 0 (highly corrupt) to 100 (very clean). While no country has a perfect score, two-thirds of countries score below 50, indicating a serious corruption problem.

Corruption translates into human suffering, with poor families being extorted for bribes to see doctors or to get access to clean drinking water. It leads to failure in the delivery of basic services like education or healthcare. It derails the building of essential infrastructure, as corrupt leaders skim funds (Transparency International, 2012).

The elections held in 2010 and the by-elections of 2012 have allowed previously excluded politicians and parties to participate in government and significant reforms to be implemented but there are many more to be done for further improvement. After more than four decades of military rule, political violence and repression of democratic movements, and conflict with minority ethnic groups, corruption has become endemic in Myanmar. While accurate information is almost impossible to obtain due to lack of transparency, Myanmar is consistently ranked at the bottom in Transparency International's Corruption Perception Index (CPI) (U4 Anti-Corruption Resource Centre, 2012). In the context of Myanmar, therefore, corruption and dishonesty in programs that would contribute to uplifting the living conditions of the people are clearly some of the major causes to poverty. Honesty and transparency in putting the planning and implementation of development programs and policies for the people will be is crucial for the growth of the country economic welfare after decades of repression and stagnation.

\section{Population Growth and Working Opportunities}

As development needs human resources, population growth can be an answer. At the same time uncontrolled population growth is related to poverty in many rural families as there is no corresponding economic growth and development. If a country or a society is unprepared economically, uncontrolled population growth can bring economic instability and unemployment which in turn will cause poverty and even social unrest.

Population growth is also sometimes blamed as a cause of poverty. Panopio and Raymundo stated that 'population growth slows down economic development' (Panopio and Raymundo, 2004, p.398). However, in the context of Myanmar where the availability of land to the growing population is not an issue, population itself cannot be a cause 
to poverty. The real issue to poverty and population growth is the lack of growth in the economy match to the needs of the growing population. Due to lack of work opportunities, growing population can become poor. In other words, national budgets must be more utilized on education, health and other basic services while creating work opportunities for the growing population can be affected as well.

\section{Social and Economic Insecurities at Present}

The newly installed civil government of the country has opened its door to international investments which used to be a dream of many people in the past decades. However, when investments are coming in, there are both positive and negative impacts. In the positive impacts, there are more financial sources coming into the country which contributes to national economic growth. More jobs are created through industrial zones, constructions and other economic establishments. However, there are negative impacts to the country socio-economic aspect. For industrial zones, lands are seized from original occupants, farmers are driven away from their lands, and workers are underpaid as wages cannot even meet the basic needs of a family. Almost every day, national journals include news of farmers protesting over confiscation their lands, workers in the factories underpaid and conflicts between workers and factory owners and lack of electricity supply to many people in Myanmar. According World Bank, lack of reliable electricity supply and clean drinking water are major obstacles in accelerating economic development:

About 75 percent of the population lacks access to electricity, and the consumption of electricity is one of the lowest in the world - 20 times less than the world average. Existing power infrastructure can only meet about half of the current demand, resulting in frequent blackouts and rationing of the electricity supply. Access to drinking water is also quite limited in many areas (World Bank, 2013).

When development fails to consider the interests of the people, such as the farmers who are evicted to make room for development of mega projects, then it is likely to lead to disaffection. Last updated: April 2013 Myanmar first became a member of the International Bank for Development and Reconstruction in 1952, the International Financial Corporation in 1956, and the International Development Association in 1962, the three institutions that make up the World Bank Group (WBG).

The Bank financed a total of 35 projects in Myanmar until 1987. In 1998, the government went into arrears to the World Bank, but remained a member, attending its Annual Meetings.

After a nearly 25 year absence, the groundwork for re-engagement in Myanmar was laid when the Bank's Board of Executive Directors endorsed an Interim Strategy for Myanmar in November 2012, reaffirming support for Myanmar government reforms to improve the lives of the people of Myanmar. This strategy will guide the Bank
Group's work in the country through March 2014, focusing on accelerating poverty reduction by helping to reform institutions to deliver better services to people during this critical transition period.

Under the Strategy, the Bank is helping the government improve economic governance and create conditions for growth and jobs by providing policy advice and technical assistance in three main areas:

- Public financial management to transparently link budgets to development priorities

- Regulatory reform to provide access to finance for microfinance borrowers and small and medium enterprises

- Private sector development to promote broad-based economic growth and job creation.

The WBG is committed to working with all stakeholders government, private sector, civil society organizations, and development partners - to encourage social accountability, and transparency as it implements this strategy.

In January 2013 the World Bank's Board approved the Myanmar Reengagement and Reform Support credit in the amount of US\$440 million. This credit facilitated the clearance of arrears to the World Bank, thereby paving the way for resumption of a full partnership to pursue Myanmar's development objectives. In addition to helping Myanmar clear its debts to creditors, this credit is supporting critical reforms needed to strengthen macroeconomic stability, improve public financial management and improve the investment climate.

In February 2013, the government and the WBG agreed to work together on Myanmar's urgent need for electric power, as well as improve the telecommunications and banking sectors. The Bank is discussing with the government a proposal to invest in producing $120 \mathrm{MW}$ of electricity, giving people in both rural and urban areas access to reliable electricity with fewer brownouts, by refurbishing existing plants with new turbines that are 2.5 times more efficient. The new turbines will produce 250 percent more electricity with the same amount of gas.

The Bank is also supporting the National Community-Driven Development Project, which empowers rural communities to choose the investments they need most, such as roads, bridges, health clinics or other priorities. This project is funded by a grant of $\$ 80$ million, and the government is contributing $\$ 6.3$ million to the total cost of the project.

Since 1987, the Bank only supported activities that were implemented through third parties, and has provided technical support to the work of other development partners. The Avian Influenza Support project, which closed in 2011, helped strengthen Myanmar's capacity to prevent, prepare for, and respond to highly pathogenic avian influenza outbreaks in animal production and to reduce the risks of the infection spreading to humans. Since 2010, the Bank has been providing technical support to the Multi-Donor Livelihood and Food Security Trust Fund (LIFT) for 
qualitative monitoring of livelihood interventions.

In the aftermath of Cyclone Nargis, which struck Myanmar in May 2008, the World Bank provided technical assistance for a post-disaster needs assessment. This assistance resulted in the Post-Nargis Joint Assessment-PONJA of July 2008, and successive Post-Nargis Social Impact Monitoring reports for November 2008, May 2009 and April 2010.

Farmers whose lands are seized do not have other stable jobs to support their families, workers who are lowly paid cannot send their children to school, and poor families cannot afford appropriate health services. In the end, there are social unrests in the country. These social unrests come from the experiences of poverty which people can no longer bear. It is not enough to look at the outward social unrest but what is more important is the inner feelings of those people of hopelessness, experiencing insecurity over their lands and threat to their family survival.

Under Chapter VIII Citizen, Fundamental Rights and Duties of the Citizens, the Myanmar Constitution (2008) is clear for the legal protection guaranteed to all citizens, ownership rights, rights to education and health care. However, the reality is, these are the very areas where many people are failed by legal protection to their lands, guarantee of their land ownership, education access and health services. The issue here is whether the constitution is lacking or it is more of a problem in enforcing the constitution in order to be effective in providing for the wellbeing of the Myanmar people. The reality for the near future in the country is, there are still possibilities for social unrests or conflicts between business establishment and farmers, factory owners and lowly paid workers because the social and economic problem of poverty is not being effectively addressed.

\section{Social Work and Poverty in Myanmar}

There is a big challenge to social workers in Myanmar today. Those who have been engaged in social work over the past years might feel that the issues discussed here are not new since they have been engaging in helping the poor by distributing food and clothes to those in need. However, it is crucial for men and women in the social work sector to evaluate their efforts in doing all those things in relation to responding to development that is based on what people really need. It is crucial for everyone involved in social work to have awareness of both material needs as well as well as the strengths possessed by the people they are trying to help. In social work, it is not only working for physical development of an individual but for the inner empowerment so that they can prepare their own future because its ultimate aim is to work for the integral development of the human being.

Social work respects the dignity of each human being. The dignity of each human being is manifested in the context of their human rights. The Universal Declaration of Human Rights (1948) guarantees the right to life, the right to health, the right to education, and above all the right to make decision regarding their future among other rights. However, there are many incidences today where it is noted that the 'human dignity is violated, exemplified in poverty, hunger and disease, a lack of proper living conditions and opportunities for education and work' (Gabriel, 1999, p.15).

Social workers identify their role as supporting social change through realization of human rights and social justice, as articulated by International Federation of Social workers:

Utilising theories of human behaviour and social systems, social work intervenes at the points where people interact with their environments. Principles of human rights and social justice are fundamental to social work (IFSW, 2012).

Men and women in social work sector have a mission and responsibility to promote the wellbeing of the people. They do this by initiating development in the areas of health, education, freedom and peace. These are not an end in themselves but a commitment to create new life and hope for those who are the victims of hopelessness, sufferings under the mismanagement of resources, and those whose social and economic rights have been taken away and those who are under uncertainties for their continuous existence. Social workers cannot afford to be reluctant to identify and work for the marginalized people in society. This world full of sufferings, people living in poverty, and subjected to by injustice and exploitation is the place where social workers are called to play an important and significant role to promote equity of rights, equity of resource distribution and self-empowerment to those who experience both physical and inner struggles in their every-day lives.

\section{Conclusions}

It has been argued in this paper that mismanagement of resources, inefficiency in governance, corruption and abuse of human rights constitute the fundamental problems in Myanmar. This highlights the importance of honesty, integrity and transparency in governance, matching of population growth to job opportunities, addressing social and economic insecurities as key to tackling poverty in Myanmar.

There is real need in Myanmar for those in the social work sector to have more understanding of the situation on the ground and setting up strategies for helping the country and Myanmar people to have better life conditions, to enjoy their human rights in all aspects of life. The social work sector is in a significant position to play leading role and initiate social work-informed policies and programs in the country.

Instinctively, parents know they are responsible for the survival of their families. However, the wages paid do not meet the basic needs of the family. The rice alone is not what a family needs, but also oil, salt and other commodities that are necessary for food. In addition to food and shelter people also need clothes. The parents want to send their children to school. The parents need to take care of the health of their children. All these are hard to achieve for urban workers on 
extremely low wages or the subsistence rice farmers who have enough rice to eat but nothing else.

The situation of the people is seriously demanding the commitment and efforts of social workers from both the Government Organizations and Non-Government Organizations understand and work to meet the needs of the people. Social work organizations would need to lobby for new legal provisions to protect the right of the people. They need to engage in social activities and services to promote the rights of children, women, and other underprivileged in the society, which include the promotion of the rights to health and education to all.

The concern of the people should not be put only on the shoulders of the government sector, but it should be together shouldered by other sectors in the society. In doing so, it is important to listen and respond to the wishes of the people so that new hope, peace, and joy can be truly experienced by the people.

\section{REFERENCES}

Constitution of Union of Myanmar, 2008.Available at http://www.scribd.com/doc/7694880/Myanmar-Constitution-2008English-version on June 13, 2013.

Burma. From http://en.wikipedia.org/wiki/Burma on August 14, 2013.

Economy of Burma. From

http://en.wikipedia.org/wiki/Economy_of_Burma on June 24, 2013.

Gabriel, Manuel G. (1999). John Paul II's Mission Theology in Asia: Agenda for the Third Millennium. Philippines: Academic Publishing Corporation.

International Federation of Social Work (2012).Code of ethics.From http://ifsw.org/policies/code-of-ethics/ on 25 May 2012.
Jung, P. S. (1990). “An Ecumenical Understanding of God's Mission in Asia." In Y.C. Lak (ed.), Atesea Occasional Papers: No.10, Doing Theology with God's Purpose in Asia. Atesea.

Kuster, V. (1994).Minjung theology and Minjung art.Mission Studies, 11(1), 108-129.

Marshall, G. (1998). A Dictionary of Sociology (2nd Edition).Oxford University Press.

Ministry of National Planning and Economic Development and UNICEF (2012). Situation Analysis of Children in Myanmar. Myanmar: Nay Pyi Taw.

Myanmar Newsweek: To Open Min and Knowledge of Society. June 13, 2013.

Myanmar. World Map. From

http://www.mapsofworld.com/country-profile/myanmar.html on June 24, 2013.

Panopio, I., and Raymundo, A. (2004).General Sociology: Focus on the Philippines.4th Edition. Quezon City: KEN Inc.

Pen, Mai Run (1995).The Educational Research and Development Assistance (ERDA) Foundation, Inc. Involvement in Social Development: A Case Study. Manila: An Unpublished Thesis presented to Asian Social Institute.

Saha, S. Ronnie (2011). Working Through Ambiguity: International NGOs in Myanmar.The Hauser Center for Nonprofit Organizations, Harvard University.

The World Bank (2013).Myanmar Overview.From http://www.worldbank.org/en/country/myanmar/overview on June 24, 2013.

Transparency International (2012).Corruption Perceptions Index 2012.From http://www.transparency.org/cpi2012/results on June 24, 2013.

U4 Anti-corruption Centre.(2012). Overview of Corruption in Burma (Myanmar). Fromhttp://www.u4.no/publications/overviewof-corruption-in-burma-myanmar/ on August 17, 2013

United Nations Development Programme, Myanmar (2011). Integrated Household Living Conditions Survey in Myanmar 2009-2010: Poverty Profile Report. 